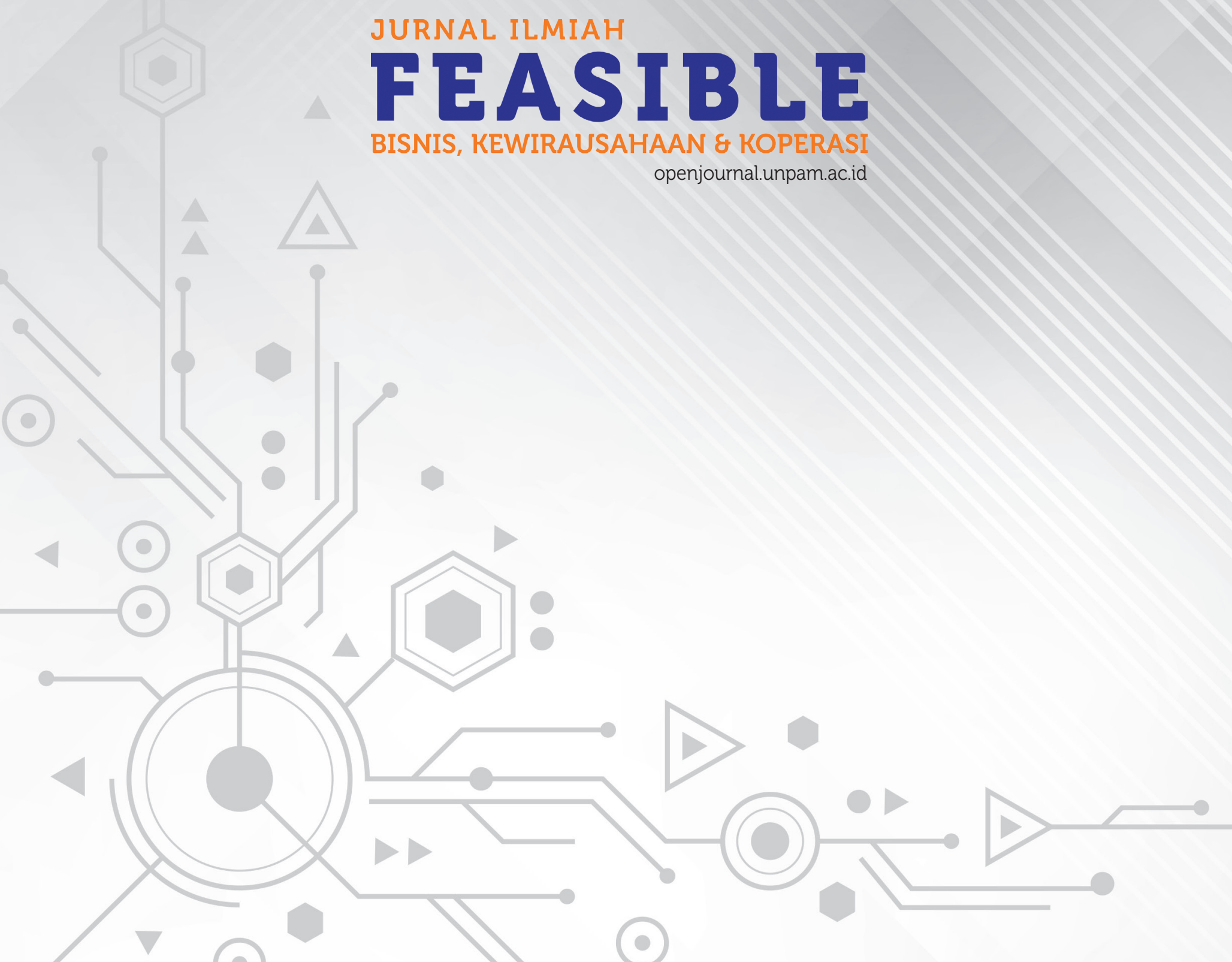




\title{
PENERAPAN SISTEM MANAJEMEN PEMASARAN PADA USAHA KECIL MENENGAH DI KABUPATEN BOGOR
}

\author{
Gojali Supiandi \\ Fakultas Ekonomi, Universitas Pamulang \\ gojalisupiandi@yahoo.com
}

\begin{abstract}
Abstrak
Perkembangan teknologi dan informasi yang cepat dan persaingan usaha yang semakin ketat telah mendorong banyak organisasi untuk mendalami dan menerapkan Sistem Management Pemasaran (SMP) dan berkembangnya studi tentang hal tersebut. Namun, kebanyakan studi cenderung biasa dilakukan pada organisasi atau perusahaan besar. Studi ini difokuskan pada hal-hal yang terkait dengan persepsi usaha kecil dan menengah terhadap SMP, pengaplikasian dan pengembangan SMP, serta penerapan manajemen pada pengusaha UKM. Penelitian ini menggunakan pendekatan kualitatif wawancara mendalam (in-depth interview) dan obeservasi langsung. Dari studi kasus usaha kecil menengah (UKM) yang berlokasi di kabupaten Bogor, studi ini menemukan bahwa pelaksanaan SMP pada usaha kecil menengah (UKM) yang diteliti masih dilakukan secara informal dan tradisional. Walaupun setiap usaha kecil menengah (UKM) telah memiliki keinginan dan kesadaran akan pentingnya penerapan SMP dan mampu mengidentifikasi pengetahuan yang dapat membantu mereka mewujudkan perencanaan strategis, masih terdapat beberapa hambatan yang menyulitkan mereka untuk menerapkan SMP tersebut. Studi ini juga mengidentifikasikan beberapa factor penting yang dapat membantu menerapan SMP pada usaha kecil menengah (UKM): (1) Dukungan dan kepemimpinan manajemen, (2) Budaya Sharing Ilmu, (3) Tekhnologi informasi, (4) Strategi dan tujuan Perusahaan, (5) Fasilitas, (6) Proses dan aktivitas, dan (7) pendidikan dan pelatihan.
\end{abstract}

Kata Kunci : Sistem Management Pemasaran (SMP), Usaha kecil Menengah (UKM), Pendekatan Kualitatif

\begin{abstract}
The rapid development of technology and information and increasingly fierce business competition has encouraged many organizations to explore and implement Marketing Management Systems (SMP) and the development of studies on them. However, most studies tend to be used for large organizations or companies. This study is focused on matters relating to the perception of small and medium enterprises to junior high schools, the application and development of junior high schools, and the application of management to SME entrepreneurs. This study uses a qualitative approach to in-depth interviews and direct observation. From the case studies of small and medium enterprises (SMEs) located in Bogor district, this study found that the implementation of SMP in small and medium enterprises (SMEs) studied was still carried out informally and traditionally. Although each small and medium-sized enterprise (SMEs) has the desire and awareness of the importance of implementing SMP and is able to identify knowledge that can help them realize strategic planning, there are still some obstacles that make it difficult for them to implement the SMP. The study also identified several important factors that could help apply SMP to small and medium enterprises (SMEs): (1) Management support and leadership, (2) Culture of Knowledge Sharing, (3) Information technology, (4) Company strategy and goals, (5) Facilities, (6) Processes and activities, and (7) education and training.
\end{abstract}

Keywords : Marketing Management Systems (SMP), Small and Medium Enterprises (SMEs), Qualitative Approaches 


\section{PENDAHULUAN \\ Latar Belakang}

Globalisasi telah menghadirkan lingkungan usaha yang baru yang ditandai dengan perkembangan teknologi dan informasi yang semakin cepat dan persaingan yang semakin ketat. Dalam lingkungan usaha yang baru ini, daya tahan dan kinerja dari sebuah organisasi sangat dipengaruhi oleh kemampuan dan kecepatan dalam membangun kompetensi yang salah satunya didasarkan kepada pengetahuan (knowledge-based competencies). Saat ini, Sistem Manajemen Pemasaran telah dipandang sebagai salah satu faktor utama untuk menciptakan dan mempertahankan keberhasilan sebuah usaha dalam meningkatkan efisiensi, inovasi dan daya saing sebuah perusahaan.

Pentingnya peranan Sistem Manajamen Pemasaran dalam keberhasilan sebuah usaha telah mendorong berkembangnya banyak studi dan penelitian dibidang tersebut sehingga menjadikannya sebagai disiplin ilmu yang berdiri sendiri. Sayangnya kebanyakan dari studi tentang Sistem Manajemen Pemasaran hanya terkait dengan perusahaan-perusahan besar saja, karena Sistem Manajemen Pemasaran pada mulanya hanya diterapkan pada perusahaan-perusahaan besar dan multinasional. Penelitian-penelitian terdahulu seringkali tidak memperhatikan perbedaan ukuran perusahan dan karakteristik-karakteristik khusus dari usaha kecil menengah (UKM) yang dapat berdampak pada penerapan Sistem Manajemen Pemasaran.

Padahal Sistem Manajemen Pemasaran bukan penting untuk perusahaan-perusahaan besar tapi juga usaha kecil menengah (UKM). Sistem Manajemen Pemasaran menjadi semakin penting untuk diterapkan dan dikembangkan oleh usaha kecil menengah (UKM) karena pada UKM, Sistem seringkali bukan hanya menyatu pada dokumen, catatan ataupun persediaan yang ada di gudang, tetapi juga pada aktivitas, proses, aturan dan kebiasaankebiasaan yang berlangsung sehari-hari. Tiwana lebih lanjut berpendapat bahwa usaha kecil menengah (UKM) sangat bergantung pada pengetahuan yang belum tercatat/terkode dan masih berada dalam pikiran individu-individu yang berada di usaha kecil menengah (UKM). Akibatnya, sebagaimana dijelaskan oleh Brossler, jika seseorang dengan pengetahuan penting meninggalkan organisasi, hal tersebut akan menciptakan gap pengetahuan yang sangat parah. Oleh karena itu, menjadi semakin penting bagi usaha kecil menengah (UKM) untuk memanfaatkan dan mengelola pengetahuan kolektif atau aset tidak kentara (intangible) yang mereka miliki.

Berdasarkan pertimbangan tersebut maka menjadi penting pula studi-studi mengenai pengaplikasian Sistem Manajamen Pemasaran pada usaha kecil menengah, khususnya yang berada di negara-negara berkembang. Hal itu penting tidak hanya untuk mengisi gap pengetahuan tentang topik tersebut, tapi juga untuk meningkatkan pemahaman akan permasalahan dan faktor-faktor penting untuk keberhasilan penerapan Sistem Manajamen Pemasaran pada usaha kecil menengah (UKM). Dari sini diharapkan mampu dihasilkan kebijakan yang dapat membantu menjamin keberhasilan pengaplikasian Sistem Manajemen Pemasaran pada usaha kecil menengah sehingga dapat meningkatkan daya saing mereka dalam iklim usaha yang makin kompetitif ini.

Studi ini bertujuan untuk mendapatkan gambaran menyeluruh mengenai pelaksanaan Sistem Manajemen Pemasaran pada usaha kecil menengah (UKM) dan mengidentifikasikan faktor-faktor penting untuk penerapan Sistem Manajemen Pemasaran dalam pengelolaan produk usaha kecil menengah (UKM). Secara khusus, penelitian ini mencoba menjawab beberapa pertanyaan berikut.

Pertama, bagaimana proses Sistem Manajemen Pemasarann dijalankan dalam usaha kecil menengah yang diteliti? Apa latar belakang dan tujuan pelaksanaan Sistem Manajemen Pemasaran pada usaha kecil menengah (UKM) mereka? Seberapa penting Sistem Manajemen Pemasaran bagi usaha mereka? Dan bagaimana Sistem Manajemen Pemasaran mendukung operational usaha kecil menengah sehari-hari?

Kedua, apakah pengetahuan mengenai pengelolaan produk dianggap penting untuk UKM? Dan usaha apa yang dilakukan oleh UKM untuk mengembangkan dan mempertahankan pengetahuan dibidang pengelolaan produk? Ketiga, apa saja tantangan dan hambatan yang dihadapi oleh UKM dalam menerapkan knowledge management (KM) dan bagaimana mereka mengatasi masalah-masalah tersebut? Keempat, faktor-faktor penting apa saja yang perlu diperhatikan dalam menerapkan dan pelaksanaan knowledge management ( $\mathrm{KM}$ ) pada UKM? Dan bagaimana masa depan perkembangan knowledge management (KM) pada usaha UKM tersebut!

Untuk menjawab pertanyaan-pertanyaan tersebut, penelitian ini akan menggunakan pendekatan kualitatif dengan menggunakan wawancara mendalam (in-depth interview) dan observasi langsung pada 3 UKM yang 
berlokasi di kabupaten Bogor. Studi ini menemukan bahwa pelaksanaan knowledge management (KM) pada ketiga UKM yang diteliti masih dilakukan secara informal dan tradisional. Walaupun setiap UKM telah memiliki keinginan dan kesadaran akan pentingnya penerapan $\mathrm{KM}$ dan mampu mengidentifikasi pengetahuan yang dapat membantu mereka mewujudkan perencanaan strategis, masih terdapat beberapa hambatan yang menyulitkan mereka untuk menerapkan knowledge management (KM) tersebut. Studi ini juga mengidentifikasikan beberapa faktor penting yang dapat membantu menerapankan knowledge managent (KM) pada UKM: (1) Dukungan dan kepemimpinan manajemen, (2) Budaya Sharing Ilmu, (3) Teknologi informasi, (4) Strategi dan tujuan Perusahaan, (5) Fasilitas, (6) Proses dan aktivitas, dan (7) pendidikan dan pelatihan.

Pembahasan pada studi ini selanjutnya diuraikan menurut urutan berikut. Pada bagian kedua akan dibahas tentang dasar teori yang menjadi landasan dan kerangka berpikir dalam studi ini. Selanjutnya, bagian ketiga akan membahas secara lengkap dan terinci tentang langkah-langkah penelitian yang dilakukan dalam studi ini. Pada bagian keempat akan diuraikan temuan-temuan yang berhasil diperoleh dari penelitian ini. Terakhir, bagian kelima membahas kesimpulan dan saran.

\section{Tinjauan Pustaka}

Pengetahuan telah menjadi salah satu aset penting yang penciptaannya, penyebaran dan pengaplikasiannya merupakan salah satu sumber utama untuk meningkatkan daya saing usaha. Pentingnya pengetahuan (knowledge) dalam sebuah perusahaan telah diyakini oleh Alawneh et al (2009). Mereka berpendapat bahwa "pengetahuan merupakan salah satu aset yang sangat penting yang mempengaruhi daya saing perusahaan tersebut". Selanjutnya, mereka juga mengatakan bahwa "salah satu cara untuk mengabadikan pengetahuan yang dimiliki oleh perusahaan dan membuatnya tersedia untuk seluruh orang di perusahaan adalah melalui penggunaan praktek-prakterk knowledge management.

Alavi dan Leidner (1999) juga telah mengamati bahwa konsep penyebaran pengetahuan di organisasi bukanlah hal baru. Ini terlihat dengan banyaknya program pembangunan pengetahuan seperti pelatihan, program pengembangan pegawai, kebijakan-kebijakan organisasi, prosedur pekerjaan dan lain-lain. Sehingga setiap organisasi sebenarnya sudah melakukan aktivitas terkait dengan pengelolaan pengetahuan. Pentingnya pengelolaan pengetahuan juga digambarkan oleh Alavi dan Leidner melalui contoh di perusahaan Dunkin'Donuts, dimana dokumen operasi manual disana telah berisikan berbagai aspek dari manajemen restoran yang meliputi resep, nutrisi, standar kesehatan dan kebersihan, standar pemasaran, prosedur memasak dan akuntansi. Dengan semua informasi tersebut tersimpan dan diupdate setiap ada perubahan maka perusahaan meminimalisir tingkat pertanyaan know-how bagi setiap manajernya di berbagai cabang. Dengan demikian tingkat efisiensi dan efektivitas pekerjaan mereka meningkat baik dari segi waktu maupun keuangan. Disamping itu secara operasional cara kerja mereka juga bisa seragam dan konsisten.

Seperti banyak perusahaan besar, UKM juga butuh belajar dan menyesuaikan diri dengan perubahan pada dunia bisnis dalam rangka mempertahankan posisinya atau bahkan memenangkan persaingan. Sebuah studi yang dilakukan oleh Edvardsson dan Durst menyimpulkan bahwa usaha kecil bisa mendapatkan keuntungan dengan menerapkan knowledge management (KM) pada setiap aktivitasnya. Hal ini didukung oleh kenyataan bahwa di hampir semua penelitian yang menjadi referensi mereka terlihat adanya keberhasilan organisasi yang mengimplementasikan knowledge management (KM) dengan pencapaian seperti kenaikan penjualan dan penurunan kerugian.

Namun, penerapan knowledge management (KM) dengan baik teryata tidaklah mudah, sebab terdapat banyak masalah dan tantangan yang harus dihadapi dalam pengimplementasikan knowledge management (KM) secara baik. Nguyen dalam thesisnya mengamati bahwa penerapan knowledge management (KM) merupakan tantangan besar bagi bisnis atau perusahaan terutama yang berasal dari negara berkembang. Banyaknya keterbatasan yang UKM miliki, seperti kurangnya permodalan dan sumber daya manusia yang berkualitas telah menghambat mereka untuk menerapkan knowledge management (KM) yang baik, walaupun mereka juga tetap harus mengaplikasikannya agar bisa bertahan dan berkembang dalam dunia bisnis yang semakin kompetitif.

Lebih lanjut, faktor budaya dan individu juga menjadi penghalang untuk penerapan KM yang baik. David dan Fahey menyatakan bahwa ada halangan budaya yang muncul saat akan mengimplementasikan knowledge management strategy (KMS) di dalam organisasi. Hal ini disebabkan budaya mempengaruhi sikap dan 
tingkah laku pengendalian terhadap tahapan pembuatan dan pengumpulan pengetahuan (knowledge creation), pendistribusian dan penggunaan pengetahuan di dalam organisasi. Oleh karena itu, perlu dibangun budaya yang kondusif dalam pengelolaan manajemen di dalam organisasi.

Selain faktor budaya, keberhasilan pengimplementasian program-program knowledge management (KM) dalam suatu organisasi usaha, termasuk UKM, juga memerlukan dukungan dari faktor-faktor lain, seperti teknologi dan struktur organisasi yang tepat. Chan dan Chao meyakini bahwa keberhasilan pengimplementasian program-program knowledge management (KM) bisa terjadi jika terdapat kombinasi yang seimbang antara faktor-faktor penting seperti dukungan manajemen, teknologi, dan struktur organisasi yang tepat. Lebih lanjut, mereka jelaskan bahwa pengetahuan (Knowledge) yang baru dapat secara efektif dibangun melalui hubungan dan interaksi antara personel, jaringan dan normanorma.

Terdapat tiga dimensi spesifik dari kemampuan infrastruktur yang diyakini oleh Chan dan Chao dapat mempengaruhi penerapan knowledge management (KM) pada UKM. Pertama adalah teknologi. Secara umum mereka menemukan bahwa kemampuan dalam menerapkan dan menggunakan teknologi pada UKM harus diperkuat. Hal ini dikarenakan berdasarkan temuan UKM ratarata kurang berinvestasi dalam teknologi untuk mendukung knowledge management (KM) dikarenakan keterbatasan finansial. Kedua adalah struktur organisasi. Mengikuti Mason dan Pauleen (2003) yang dikutip oleh Chan dan Chao mereka berpendapat bahwa dibutuhkan skema penghargaan dan insentif yang sesuai dengan struktur organisasi UKM yang biasanya kecil dan simple. Hal ini diyakini dapat memotivasi dan memunculkan semangat untuk lebih banyak melakukan knowledge transfer dan sharing diantara personel. Selain itu dibutuhkan juga alur perpindahan pengetahuan yang sesuai dengan struktur UKM.

Ketiga adalah Budaya/Kultur. Mereka menemukan bahwa UKM pada umumnya sudah memiliki kesadaran akan pentingnya knowledge management (KM) dalam rangka memenangkan kompetisi bisnis. Akan tetapi mereka tetap membutuhkan dukungan penuh dari seluruh manajemen perusahaan dalam hal pelaksanaan dan pengawasan. Manajemen juga bisa memberikan contoh dan memperlihatkan kepada para pekerja bahwa knowledge management (KM) itu bukan cuma sekedar konsep akan tetapi betul-betul harus diterapkan secara nyata untuk meningkatkan kemampuan perorangan dalam rangka meningkatkan kompetensi organisasi (perusahaan).

\section{METODE}

Penelitian ini akan menggunakan pendekatan kualitatif dengan menggunakan indepthinterview dan obeservasi langsung pada pemilik dan karyawan yang terdapat pada tiga UKM yang berdomisili di daerah Kabupaten Bogor. Kriteria UKM yang dipilih berdasarkan jumlah karyawan, yaitu usaha yang memiliki tenaga kerja kurang dari 50 orang. Kriteria pemilihan UKM ini mengikuti kriteria yang biasa diterapkan oleh Badan Pusat Statistik (BPS) dalam mengelompokkan ukuran dan jenis usaha.

Proses pengumpulan data dilakukan melalui kunjungan dan tatap muka langsung kepada pemilik dan karyawan di tiga UKM yang menjadi sample. Pertanyaan-pertanyaan wawancara dibuat sebagai acuan dan agar wawancara tetap sesuai dengan tujuan yang ingin dicapai dari penelitian ini. Proses wawancara untuk tiap responden dilakukan selama sekitar 1-2 jam. Cara ini juga diharapkan mampu mendapatkan informasi langsung dari para responden mengenai pengetahuan dan pemahaman mereka akan penerapan knowledge management (KM) pada UKM. Hasil dari wawancara ini akan digabungkan dengan berbagai bukti dan termuan dari hasil observasi dan berbagai dokumen lainnya untuk kemudian dianalisa dan meningkatkan keakuratan dari keseluruhan temuan yang dirumuskan dari studi ini.

Dari proses analisa data yang berasal dari wawancara ini beserta analisanya akan didapat perbedaan, persamaan, dan pola atau trend yang menjadi dasar untuk pembuktian dari peryataan atau kesimpulan dari temuan yang akan diambil. Walaupun jumlah sample yang dipilih ini (tiga lokasi UKM) mungkin tampaknya kecil jika dibandingkan dengan populasi UKM yang terdapat di Kota Bogor, jumlah tersebut cukup representatif dan dapat diterima dengan mempertimbangkan pilihan pendekatan studi kasus dalam penelitian ini. Lebih lanjut, dengan menerapkan prisip metode triangulation, penelitian ini diharapkan mampu memenuhi validitas dan kredibilitas dari studi kualitatif.

\section{HASIL dan PEMBAHASAN}

Penelitian ini berhasil mendapatkan kesediaan pemilik dan karyawan dari tiga lokasi 
UKM yang berdomisili di kabupaten Bogor. Tiga UKM yang berpartisipasi terdiri dari dua Usaha Kecil dan satu Usaha menengah. Penelitian ini berhasil melakukan wawancara langsung kepada para pemilik dan karyawan dari tiga UKM tersebut dan melakukan observasi langsung. Namun, penelitian ini tidak berhasil mendapatkan dokumen-dokumen pengetahuan yang ada di perusahaan seperti SOP, pedoman-pedoman dan yang lainnya tidak bias. Hal ini dikarenakan minim dan hampir tidak adanya dokumentasi dan catatancatatan berkaitan dengan aturan, prosedur, tata cara laksana yang berhubungan dengan pengetahuan penting perusahaan. Responden yang diinterview dari ketiga UKM rata-rata adalah pemilik dan staf bagian keuangan. Untuk menjamin kerahasiaan responden, nama responden dan usaha mereka kami samarkan.

Berikut adalah penjelasan lebih lanjut tentang profil usaha ketiga UKM yang diteliti dan temuan-temuan lainnya tentang penerapan knowledge management (KM) pada usaha mereka.

\section{Profil Umum Perusahaan}

Tabel 1 menjelaskan data profil umum tentang UKM yang berpartisipasi dalam penelitian ini. Secara umum, terdapat berbagai perbedaan yang dimiliki oleh UKM tersebut. Menurut bidang usahanya, ketiga UKM menjalani bidang usaha yang beragam, mulai dari produksi dan penjualan kue, usaha dagang alat-alat kemasan kue dan Jasa servis dan perbaikan alat rumah tangga. Dari jumlah karyawan dan omzet nya, satu perusahaan tergolong sebagai usaha menengah ( ${ }^{\prime}$ bakery and cake), sedangkan dua lainnya tergolong kedalam usaha kecil (usaha dagang alat-alat kemasan kue dan Jasa servis dan perbaikan alat rumah tangga). Jumlah karyawan pada usaha kecil berkisar dari 2-5 orang, sementara UKM jenis usaha menengah memiliki personel sebanyak 20 orang. Menurut usianya, satu perusahaan telah berusia lebih dari 10 tahun, sementara dua lainnya berusia 5 tahun.

Meskipun demikian, UKM yang diteliti memiliki satu persamaan yaitu dimiliki oleh perseorangan dan merupakan perusahaan keluarga. Pemilik memiliki keterkaitan dan keterlibatan yang cukup besar terutama terkait pelaksanaan aktivitas dan pengambilan keputusan yang bersifat strategis.

\begin{tabular}{c|c|c|c|c|}
\hline \multicolumn{5}{|c}{ Tabel 1. Profil Usaha UKM } \\
$\begin{array}{c}\text { Nama } \\
\text { Perusahaan }\end{array}$ & $\begin{array}{c}\text { Lama } \\
\text { berdiri }\end{array}$ & $\begin{array}{c}\text { Jumlah } \\
\text { Pekerja }\end{array}$ & Status Usaha & Jenis Usaha \\
\hline UKM A & 10 tahun & 20 orang & $\begin{array}{c}\text { Perusahaan } \\
\text { perorangan }\end{array}$ & $\begin{array}{c}\text { Bakery \& } \\
\text { Cake }\end{array}$ \\
\hline
\end{tabular}

\begin{tabular}{|c|c|c|c|c|}
\hline UKM B & 5 tahun & 3 orang & $\begin{array}{c}\text { Perusahaan } \\
\text { perorangan }\end{array}$ & $\begin{array}{c}\text { Dagang Alat } \\
\text { kemasan } \\
\text { kue/mika }\end{array}$ \\
\hline UKM C & 5 tahun & 2 orang & $\begin{array}{c}\text { Perusahaan } \\
\text { perorangan }\end{array}$ & $\begin{array}{c}\text { service } \\
\text { alat rumah } \\
\text { tangga }\end{array}$ \\
\hline \multicolumn{2}{|c}{ Sumber: Diolah oleh Penulis } \\
\hline
\end{tabular}

\section{Penerapan Management \\ Pemasaran pada UKM}

Setiap organisasi tentunya memiliki strategi pemasaran yang harus dijalankan dalam melaksanakan kegiatan bisnisnya. Strategi merupakan sarana organisasi yang digunakan untuk mencapai tujuannya. Salah satu bentuk dari strategi bisnis adalah strategi pemasaran. Tetapi banyak kasus UKM di Indonesia yang tidak dapat melakukan strategi pemasaran yang tepat. Cenderung UKM di Indonesia hanya "menunggu konsumen" dan monoton dalam melakukan kegiatan pemasaran. Menurut Ina Primiana dalam bukunya Menggerakan Sektor Rill UKM \& Industri (2009), selain permodalan yang menjadi pokok permasalahan bagi UKM berkaitan dengan pemasaran, lebih dikarenakan:

1. Sulitnya akses pasar dikarenakan keterbatasan-keterbatasan antara lain membaca selera pasar, mengenal pesaing dan produknya, memposisikan produknya di pasar, mengenal kelemahan produknya diantara produk pesaing.

2. Keterbatasan SDM. Untuk usaha Mikro dan Kecil pada umumnya pemilik masih melakukan semua kegiatan sendiri atau dibantu beberapa pegawai seperti produksi atau pengawasan produksi, sehingga mencari pasar menjadi terbengkalai.

3. Strandarisasi produk lemah, hal ini menyebabkan pesanan dikembalikan (retur) dikarenakan kualitas produk yang dihasilkan spesifiknya tidak sesuai dengan pada saat pesan.

4. Hilangnya kepercayaan pelanggan akibat ketidakmampuan memenuhi permintaan dalam jumlah besar, antara lain dikarenakan tidak tersedianya dana untuk memenuhi permintaan tersebut.

Berdasarkan galeriukm.web.id, Permasalahan mendasar yang sering dihadapi pemilik Usaha Kecil adalah lemahnya penetrasi pasar dan kurang luasnya jangkauan wilayah pemasaran. Karena itu untuk memajukan usaha kecil yang memiliki daya saing yang kuat adalah dengan membangun strategi pemasaran yang baik dan tepat sasaran. Pemasaran merupakan upaya mengatur strategi dan cara agar konsumen mau mengeluarkan uang yang mereka miliki untuk menggunakan produk 
atau jasa yang dimiliki sebuah perusahaan, dalam hal ini usaha kecil dan menengah. Dengan strategi pemasaran yang baik posisi usaha kecil dan menengah menjadi kuat dan patut diperhitungkan dalam kegiatan ekonomi nasional yang akhirnya membawa keuntungan bagi usaha tersebut. Strategi pemasaran berkaitan dengan bagaimana cara meyakinkan pembeli/pelanggan terhadap produk yang akan dijual. Untuk dapat meyakinkan pembeli si penjual harus memiliki keyakinan bahwa produk yang dijual memang patut dibeli. Karena itu perlu dipertimbangkan beberapa aspek dalam menentukan strategi pemasaran yang akan dijalankan. Berdasarkan permasalahan pemasaran yang dialami oleh UKM di Indonesia. Berikut beberapa cara yang dapat dilakukan untuk memperbaiki serta meningkatan strategi pemasaran yang tepat untuk UKM di Indonesia.

\section{Melakukan STP (Segmenting, Targeting, dan Positioning)}

Segmentasi pasar, strategi penentuan pasar, dan strategi penentuan posisi saling berhubungan satu dengan lainnya. Segmentasi pasar (segmenting) adalah proses menempatkan konsumen dalam subkelompok di pasar-produk, sehingga para pembeli memiliki tanggapan yang hampir sama dengan strategi pemasaran dalam penentuan posisi perusahaan. Oleh karenanya, segmentasi merupakan proses identifikasi yang bertujuan untuk mendapatkan pembeli dalam keseluruhan pasar.

Segmentasi mengidentifikasikan kelompok konsumen dalam pasar-produk, di mana setiap segmen terdiri dari pembeli dengan preferensi produk yang hampir sama. Setiap segmen merupakan pasar sasaran organisasi untuk bersaing di pasar. Segmentasi memberikan peluang bagi perusahaan untuk menyesuaikan produk atau jasanya dengan permintaan pembeli secara efektif. Kepuasan konsumen dapat ditingkatkan dengan pemfokusan segmen. Segmentasi dapat terjadi pada struktur pasar dengan berbagai produk generik, berbagai jenis produk, dan bentuk produk. Penentuan pasar sasaran (targeting) merupakan proses pengevaluasian dan pemilihan setiap segmen yang akan dilayani oleh perusahaan. Perusahaan dapat saja menetapkan satu, sedikit, atau beberapa dari segmen pasar yang telah dilakukan.

(Galeri UKM) Menentukan target pasar yang sudah tertentu merupakan strategi pemasaran agar tidak salah menjual produk pada orang yang tidak tepat. Salah satu permasalahan usaha kecil adalah kesulitan un- tuk untuk menentukan segmen pasar dari hasil produknya, apakah diperuntukkan bagi masyarakat kelas menengah atas atau untuk menengah bawah. Bisnis Usaha kecil sejak awal harus menentukan bisnisnya diarahkan untuk kelas mana. Dengan menentukan target pasar yang dituju, perusahaan bisa memberikan satu nilai tambah yang menjadi pembeda dibandingkan dengan para pesaingnya. Nilai tambah inilah yang disebut sebagai differensiasi. Dengan differensiasi yang kuat, bisa menjadi senjata dalam menghadapi berbagai persaingan.

\section{Penerapan Knowledge Management pada UKM}

Pengetahuan yang dianggap paling penting oleh ketiga UKM yang diteliti adalah pengetahuan yang kaitan dengan pelaksanaan kegiatan operasional, pengelolaan keuangan sederhana, manajemen, dan semua pengetahuan yang berkaitan dengan pelayanan prima (tepat waktu, melayani dengan baik, mendahulukan kepuasan pelanggan). Selain itu, integritas dan loyalitas merupakan hal yang tidak bisa dilepaskan dari pembentukan pengetahuan utama yang biasanya dipelajari melalui pengalaman dan pergaulan selama bekerja.

Pengelolaan operasional usaha pada ketiga UKM yang diteliti umumnya masih bersifat tradisional dan kekeluargaan, dimana pemilik dan keluarga memainkan peranan sentral dalam pengelolaan pengetahuan terutama yang terkait dengan pengetahuan dan informasi keuangan. Baik pada perusahaan kecil dan menengah, pemilik adalah Pengetahuan yang dianggap paling penting oleh ketiga UKM yang diteliti adalah pengetahuan yang kaitan dengan pelaksanaan kegiatan pengambil keputusan utama dalam pengelolaan pengetahuan. Keputusan untuk update ilmu dan dokumentasi semuanya harus bersumber dari pemilik tanpa di delegasikan. Namun demikian, pada usaha menengah terdapat sedikit perbedaan. Pada perusahaan menengah aliran pengetahuan tetap terjadi secara vertical dan horizontal, tetapi beberapa pengetahuan dan informasi sudah di pegang oleh berbagai lapisan manajemen perusahan mulai dari manajer, supervisor, kordinator sampai staf. Beberapa pengetahuan yang dianggap paling penting dan masih dipegang oleh pemilik perusahaan menengah yang diteliti antara lain: (a) inovasi terutama berkaitan dengan pembuatan produk dan pemasaran dan (b) manajemen pengelolaan termasuk keuangan dan akuntansi.

- Saya yang lansung mengajari semua staf yang masuk di usaha saya ini. Penge- 
tahuan baru di perusahaan ini berasal dari saya dan pengalaman anak buah saya. (Grosir mika/kemasan kue)

- Keputusan apapun semua lansung dari pimpinan inisiatif dan pengambilan keputusannya, saya biasanya tidak diberitahu sama sekali... (Pimpinan)

Pada usaha kecil, transfer pengetahuan atau proses memperbarui (update) informasi dan pengetahuan karyawan biasanya dilakukan melalui training internal (In-house training) yang didominasi oleh pemilik. Arus sharing ilmu dilakukan secara rutin baik secara vertical (Pemilik ke karyawan) dan horizontal (antara karyawan dengan karyawan), walaupun transfer pengertahuan biasanya lebih sering terjadi melalui jalur vertikal. Pada kedua usaha kecil, ilmu berpusat ke pemilik. Dimana pemilik terbuka membagi semua ilmu yang dimilikinya kepada semua pegawai. Dalam hal ini pemilik mempelajari semua ilmu-ilmu yang berkaitan dengan bidang usahanya (kue dan bahan kue), kemudian pengalamannya dibagi ke para pekerjanya. Antar pekerja juga di motivasi untuk saling belajar dan membagi ilmu. Pemilik tidak memiliki ketakutan atau kekhawatiran jika ilmunya diserap oleh bawahan yang sewaktu-waktu bisa meninggalkan perusahaan untuk berbagai alasan. Pemilik meyakini bahwa in-house training yang dilakukan secara terus menerus secara informal ini efektif dalam pembentukan pengetahuan karyawan. Itu juga yang menjadi salah satu alasan bagi pemilik untuk menyatakan bahwa mereka tidak membutuhkan input karyawan yang sudah profesional di bidang usahanya, karena yang penting mereka bisa belajar dengan cepat di perusahaan.

- Kita tidak terlalu membutuhkan pegawai yang sudah pandai karena mereka akan kita latih disini. (pemilik Grosirl/mika/ kemasan kue)

- $\quad$ Saya senang membagi ilmu kepada pegawai baru yang haus akan pengetahuan baru, sehingga lebih mudah mengajarkan mereka sekaligus memasukkan nilai-nilai yang ingin saya bekalkan kepada mereka agar menjadi staf yang amanah dan disiplin. (pemilik Grosir)

Pelaksanaan transfer ilmu di antara semua personel perusahaan pada usaha menengah agak berbeda dengan usaha kecil. Hal ini disebabkan lapisan level karyawan dan pekerjaan lebih banyak dibanding usaha kecil.

Di mana untuk level operasional kultur sharing ilmu terbuka baik antara supervisor, koordinator maupun staf yang ada dibawahnya. Ilmu yang ditransfer dan disharing berkaitan dengan pekerjaan yang akan mereka lakukan. Sedangkan untuk level manajer atau posisi penting perusahaan berkaitan dengan pembuatan segmen pasar dan pengelolaan keuangan, pertukaran informasi dilakukan secara eksklusif dengan pemilik. Semua manager di posisi tersebut diberi insentif yang menarik dan dibina hubungan kekeluargaan dengan pemilik, sehingga semua manager dan posisi kunci loyal terhadap perusahaan dan masih dipegang oleh orang yang sama.

- $\quad$ kultur budaya membagi ilmu di Perusahaan ini pasti selalu ada terutama dalam ment raining dan transfer ilmu dari yang lama ke pegawai baru, pegawai diberi masa percobaan 3 bulan jika cocok dari kedua belah pihak maka akan dilanjutkan... biasanya ilmu di satu bagian di share dengan staf tertentu sehingga tidak satu org yang memiliki pengetahuan tertentu, sehingga kalo ada yg tidak hadir atau berhalangan akan ada staf lain yang bisa memback up. (Karyawan Bakery \& Cake)

Waktu tinggal karyawan juga tidak terpengaruh dengan pola keterbukaan dan budaya transfer ilmu, baik pada usaha kecil ataupun menengah. Dari pengalaman kedua usaha kecil (UK), keterbukaan pemilik dalam membagi ilmunya terlihat tidak mempengaruhi waktu tinggal pekerja di perusahaan. Misalnya pada UK pertama yang bergerak di penjualan alat mika/kemasan kue, waktu tinggalnya berkisar antara 1.5 sampe 2 tahun. Sementara UK yang kedua memiliki prinsip keterbukaan transfer ilmu yang sama oleh pemilik, akan tetapi ratarata pegawainya bertahan antara 1-5 tahun. Tidak jauh berbeda dengan kedua usaha kecil, pada usaha menengah waktu tinggal karyawan jugatidakterpengaruh dengan polaketerbukaan dan budaya transfer ilmu. Salah satu strategi perusahaan untuk mempertahankan karyawan dengan pengetahuan yang penting untuk perusahaan adalah dengan memberikan insentif yang baik dan membangun suasana kekeluargaan.

Walaupun pelaksanaan knowledge management (KM) pada semua usaha diatas masih terbilang tradisional dan sederhana, akan tetapi tujuan penerapan knowledge management (KM) sederhana dengan budaya sharing ilmu di perusahaan mereka ini cukup jelas. Tujuannya adalah untuk memperlancar kegiatan operasional dan pelayanan kepada pelanggan. Misalnya pada usaha kecil, dengan ilmu yang hampir merata diantara semua personelnya, maka siapapun bisa melayani pelanggan terutama jika sedang "peak time" atau banyak pelanggan 
datang disaat bersamaan. Sejalan dengan itu walaupun di usaha menengah sharing ilmu terjadi secara berlapis pada beberapa tingkatan, akan tetapi juga ditujukan untuk kelancaran pelaksanaan semua aktivitas perusahaan dan demi kelangsungan jalannya perusahaan dimasa depan.

\section{Pentingnya Pengelolaan Pengetahuan Keuangan pada UKM}

Pemilik memainkan peranan yang central pada kegiatan operasional khususnya dalam proses pengelolaan dan pelaporan keuangan perusahaan, dimana pemilik ikut membantu dan mengarahkannya. Hal ini dikarenakan pengetahuan mengenai pengelolaan keuangan diyakini semua UKM sebagai pengetahuan penting dalam menjaga kelancaran kegiatan operasional dan aktivitas perusahaan kedepannya. Sehingga pemilik juga terlibat secara konsisten pada pengelolaan pengetahuan dan pembaharuan informasi di bidang ini. Di setiap perusahaan hanya keluarga dan orangorang kepercayaan yang di beri kepercayaan mengelola keuangan. Alur informasi dan pengetahuan di bagian ini juga hanya dibagi dan ditransfer secara eksklusif dengan pemilik.

- Pencatatan dan pelaporan keuangan semua dilakukan oleh kami sekeluarga secara bergantian, pegawai hanya kami minta membuat catatan pada saat ada barang yang terjual dan semua dikonfirmasi pada saat salah satu pemilik merekap penjualan diakhir hari tersebut. (Pemilik Grosir)

- Semua catatan dan cara mencatatnya diajarkan dan dipantau oleh bapak (Pemilik). Kalau ada informasi apapun berkaitan keuangan semua keputusan mengenai apa yang harus saya lakukan dikomando oleh beliau, bahkan kalau saya berhalangan hadir beliau yang mengambil alih catatan keuangan penjualan. (staf keuanganl/Grosir)

- $\quad k a l a u$ pekerjaan saya yang penting tidak bisa didokumentasikan karena instruksi pimpinan yang boleh tau mengenai keuangan ini hanya saya dan pimpinan. Yang bs saya delegasikan ke staf dibawah saya hanya pembayaran atau pencatatan umum dan rutin. Kalau saya libur atau berhalangan maka semua transaksi dan pencatatatan keuangan ditunda pemrosesannya sampai saya masuk kembali. (Karyawan Grosir)

Namun, khusus pada usaha menengah, mereka bekerja sama dengan tim satu kepala toko untuk membantu pembuatan laporan keuangan terutama yang nanti akan ditujukan ke pihak perusahaan. Dimulai dengan staf keuangannya melakukan pencatatan dan pelaporan secara sederhana. Kemudian laporan tersebut dikirimkan ke pimpinan perusahaan dengan format yang benar dan sesuai kebutuhan.

- kami juga bekerjasama tim dan konsultasi dengan salah satu kepala toko, laporan kami nanti dikirim ke kepala toko tersebut dan dibikinkan laporan yang sesuai dengan kebutuhan. Dalam pembuatan laporan perusahaan memang sangat bergantung kepada kepala toko dalam pelaporan keuangan. (Karyawan Bakery \& Cake)

Sementara itu, semua UKM yang diwawancara menganggap bahwa pengelolaan keuangan itu sangat penting untuk mereka lakukan dimasa depan. Sebagian besar sudah mulai berniat dan memikirkan penggunaan teknologi dalam pengelolaan keuangan dan perbaikan (update) ilmu dari karyawan pemegang keuangan, akan tetapi masih belum ada yang memastikan kapan hal tersebut akan mereka wujudkan. Salah satu keluhan yang mereka sebut sebagai sebab utamanya adalah jumlah staf keuangan yang terbatas sementara tanggung jawab dan pekerjaannya setiap hari sudah cukup menyita waktu. Sehingga mereka takut jika penggunaan teknologi akan mengganggu jalannya pekerjaan staf tersebut. Lebih jauh lagi jika mereka harus merekrut pegawai baru, hal tersebut akan menambah biaya dari sisi pengeluaran gaji karyawan.

\section{Hambatan dan Faktor-faktor Penerapan knowledge management (KM) pada UKM}

Terdapat beberapa hambatan dalam pelaksanaan KM yang diidentifikasi secara umum melalui wawancara dan observasi pada ketiga UKM yang diteliti. Pertama, dana yang harus dikeluarkan jika harus mengirim karyawan untuk training dalam rangka pembaharuan pengetahuan. Kedua, waktu karyawan yang akan tersita untuk mengikuti training atau mendokumentasikan pekerjaannya sehingga dikhawatirkan tugas utamanya menjadi tidak terselesaikan dengan baik. Ketiga, kemampuan daya serap pengetahuan oleh karyawan yang mungkin tidak merata, sehingga mungkin akan memperlambat proses transfer ilmu. $\mathrm{Ke}$ empat, kerahasiaan informasi terutama berkaitan dengan pengelolaan keuangan yang menyebabkan sharing ilmu pada bidang tertentu terutama berkaitan dengan pengelolaan keuangan masih sulit dilakukan. Hal ini membuat pembagian pengetahuan dan infor- 
masi hanya dilakukan oleh karyawan bagian keuangan kepada orang orang tertentu saja misalnya pemilik.

Sementara itu, penelitian ini juga mendapati bahwa ketiga UKM yang diwawancara mengakui beberapa faktor utama kesuksesan penerapan KM di UKM yang telah diajukan oleh wong (2005). Beberapa faktor tersebut antara lain sebagai berikut. Pertama, dukungan dan kepemimpinan manajemen perusahaan. Manajemen pada ketiga UKM ini lebih dimaksudkan kepada pemilik. Dalam hal ini dikarenakan pemilik yang merupakan pengambil keputusan utama dalam perusahaan, maka keputusan-keputusan pemilik berkaitan dengan cara dan pelaksanaan transfer ilmu dan pembaharuan pengetahuan pada perusahaan sangat ditentukan oleh mereka. Kedua, budaya dan kebiasaan yang ada diperusahaan terkait berbagi ilmu (sharing knowledge). Penggunaan teknologi informasi dalam mendokumentasikan pengetahuan dan informasi-informasi penting perusahaan. Strategi dan tujuan perusahaan apakah memerlukan pengetahuan yang selalu baru dan mudah diakses. Ketiga, fasilitas/infrastruktur yang dimiliki oleh perusahaan. Proses dan aktivitas yang ada di perusahaan. Hal ini terkait dengan kelancaran dan kemudahan pelaksanaan proses dan aktivitas pada perusahaan yang berkaitan dengan ada tidaknya penerapan KM. Keempat, kesempatan mendapatkan pendidikan dan training yang diberikan oleh perusahaan kepada setiap karyawannya.

\section{SIMPULAN}

Studi ini bertujuan untuk mendapatkan gambaran menyeluruh mengenai pelaksanaan knowledge management (KM) pada UKM dan mengidentifikasikan faktor-faktor penting untuk penerapan $\mathrm{KM}$ dalam pengelolaan keuangan UKM. Studi ini difokuskan pada halhal yang terkait dengan persepsi usaha mikro, kecil dan menengah (UKM) terhadap KM, pengaplikasian dan pengembangan KM, serta faktor penting dalam keberhasilan penerapan KM pada UKM. Penelitian ini menggunakan pendekatan kualitatif dengan menggunakan wawancara mendalam (in-depth interview) dan obeservasi langsung pada tiga UMKM yang berlokasi di Kabupaten Bogor.

Studi ini menemukan bahwa pelaksanaan KM pada ketiga UKM yang diteliti masih dilakukan secara informal dan tradisional. Pada Usaha kecil pemilik adalah poros ilmu dan pengetahuan yang selalu melakukan update dan sharing ilmu kepada personelnya. Sementara pada Usaha menengah walaupun bukan merupakan poros ilmu dan tidak berinteraksi secara lansung dalam transfer pengetahuan, akan tetapi pemilik memantau semua proses secara konsisten dan lansung bertindak sebagai pengambil keputusan tunggal terhadap semua aktivitas yang berkaitan dengan perpindahan pengetahuan.

Khusus pengetahuan dalam pengelolaan keuangan oleh pemilik dari ketiga UKM hanya dikelola oleh orang-orang tertentu yang dipercaya. Biasanya berasal dari keluarga yang sama dengan pemilik. Hal ini dikarenakan informasi dan pengetahuan mengenai pengelolaan keuangan bersifat rahasia dan hanya dibagi secara eksklusif dengan pemilik.

Walaupun setiap UKM telah memiliki keinginan dan kesadaran akan pentingnya penerapan KM dan mampu mengidentifikasi pengetahuan yang dapat membantu mereka mewujudkan perencanaan strategis, masih terdapat beberapa hambatan yang menyulitkan mereka untuk menerapkan KM tersebut. Beberapa hambatan itu antara lain: keterbatasan dana untuk training karyawan, keterbatasan waktu, rendahnya kemampuan daya serap karyawan, dan kerahasiaan informasi terkait pengelolaan keuangan perusahaan. Dikarenakan hambatan tersebut biasanya perusahaan lebih cenderung untuk melakukan sharing ilmu secara informal, atau melakukan in house training dengan memanggil ahli untuk mengadakan pelatihan di dalam perusahaan. Dan pembagian pengetahuan dan informasi hanya dilakukan oleh karyawan bagian keuangan kepada orang orang tertentu saja misalnya pemilik.

Studi ini juga mengidentifikasikan beberapa factor penting yang dapat membantu keberhasilan penerapan KM pada UKM: (1) Dukungan dan kepemimpinan manajemen, (2) Budaya Sharing Ilmu, (3) Tekhnologi informasi, (4) Strategi dan tujuan Perusahaan, (5) Fasilitas, (6) Proses dan aktivitas, dan (7) pendidikan dan pelatihan.

Penelitian ini memiliki beberapa kelemahan. Pertama, penelitian ini masih terbatas meneliti dan mengidentifikasi faktor-faktor penting untuk keberhasilan penerapan knowledge management dalam pengelolaan keuangan pada usaha kecil dan menengah di kota Padang saja. Selain itu cakupan penerapan KM juga masih terfokus ke aktivitas pengelolaan keuangan saja. Untuk itu cakupan penelitian dan analisa masih relatif kecil. Kedua, sampel yang digunakan dalam studi ini relatif cukup kecil (3 UKM). Hal ini dikarenakan dari sekitar 10 UKM yang dihubungi hanya tiga UKM saja 
yang bersedia terlibat dalam penelitian.

Untuk itu, studi ini menyarankan untuk penelitian selanjutnya agar cakupan area penelitian bisa diambil dari populasi UKM di kota lain atau juga bisa diperluas misalnya mencakup semua UKM di Jabodetabek, sehingga penelitian yang dihasilkan memiliki daya generalisasi dan manfaat yang lebih luas. Selain perluasan cakupan area penelitian menjadi satu provinsi, bisa juga akan memperluas jumlah dan bidang responden menjadi meliputi semua aktivitas dan tidak terfokus pada pengelolaan keuangan saja. Lebih jauh lagi dapat pula dilakukan variasi bentuk penelitian.

\section{DAFTAR PUSTAKA}

Alavi, M., \& Leidner, D. E.,February 1999. Knowledge Management System: Issues, Challenges and Benefits. Journal Communication of The Association for Information System. Volume 1.

Alawneh, A. A., Abuali, A., \& Almarabeh, T. Y., 2009. The Role of Knowledge Management in Enhancing the Competitiveness of Small and Medium-Sized Enterprises (SMEs). Communications of the IBIMA Volume 10, ISSN: 1943-7765.

r ssler, P., 1999. Knowledge Management at a Software Engineering Company - An Experience Report.

Workshop on Learning Software Organizations, LSO'99, Kaiserslautern, Germany, pp. 163- 170.

Chan, I., \& Chao, C. K. 2008. Knowledge management in small and medium-sized enterprises. Communications of the ACM, 51(4), 83-88.

Daud, Salina, and Wan Fadzila Wan Yusuf. (2008). An empirical Study of Knowledge Management Processes in Small and Medium Enterprises".Communication of the IBIMA, Volume 4.

Davenport, T. and L. Prusak. 1998. Working knowledge: How organizations manage what they know. Harvard Business School Press.

David,W.,\&Fahey,L.2000.Diagnosing cultural barriers to knowledge management. The Academy of management executive, 14(4), 113-127..

Edvardsson I.R and Durst, S. 2013. The Benefits of Knowledge Management in Small and Medium Sized Enterprises. ProcediaSocial and Behavioural Sciences no.81. Elsevier.

Nguyen T.H.H. 2011. Knowledge Management in Small and Medium Sized Enterprises in Developing Countries (Case Study: Vietnam). Thesis. Thomas Bata University. Czech Republic.

Okunoye, A. and Karsten, H. (2002), -Where the global needs the local: variation in enablers in the knowledge management process, Journal of Global Information Technology Management, Vol. 5 No. 3, pp. 12-31.

Tiwana,A.(2000),TheKnowledgeManagement Toolkit: Practical Techniques for Building a Knowledge Management System, Prentice Hall, Upper Saddle River, NJ. 